\title{
Aplikasi Matlab pada Teknologi Pencitraan Medis
}

\author{
Atina $^{1 *}$ \\ ${ }^{1}$ Program Studi Fisika, FMIPA Universitas PGRI Palembang, \\ Palembang 30251, Indonesia \\ *e-mail: atina.salsabila@gmail.com
}

\begin{abstract}
Abstrak
Matlab (Matrix Laboratory) adalah software/prangkat lunak yang dikembangkan oleh Mathworks, Inc dengan memanfaatkan matriks dalam penggunaannya. Salah satu kegunaan dari Matlab secara umum adalah untuk pengembangan di bidang komputasi yaitu pengembangan pemrograman/software. Sehingga Matlab dapat diaplikasikan dalam teknologi pencitraan medis khususnya citra medis hasil radiografi digital. Aplikasi pemanfaatan Matlab dalam teknologi pencitraan medis telah berkembang melalui algoritma yang terus dikembangkan dengan berbagai tujuan, mulai dari identifikasi/deteksi, segmentasi, simulasi bahkan sampai dengan pengembangan pemrograman alat medis. Aplikasi Matlab dalam teknologi pencitraan medis khususnya radiografi digital diantaranya dalam proses segmentasi dengan tujuan deteksi kelainan, simulasi dan pengembangan program.
\end{abstract}

Kata Kunci: Matlab, aplikasi, teknologi pencitraan medis, citra digital

\section{Maltab Application in Medical Imaging Technology}

\begin{abstract}
Matlab (Matrix Laboratory) is a software developed by Mathworks, Inc. by utilizing the matrix in its use. One of the uses of Matlab in general is for development in the field of computing, namely programming / software development. So that Matlab can be applied in medical imaging technology, especially medical images from digital radiography. The application of using Matlab in medical imaging technology has evolved through algorithms that continue to be developed with various objectives, ranging from identification / detection, segmentation, simulation and even to the development of medical device programming. The application of Matlab in medical imaging technology, especially digital radiography, is in the process of segmentation with the aim of detecting abnormalities, simulations and program development.
\end{abstract}

Keywords: Matlab, application, medical imaging technology, digital image

\section{PENDAHULUAN}

Matrix Laboratory (Matlab) adalah perangkat lunak yang menggunakan dasar matrix dalam pemanfaatannya. Matrix yang digunakan pada Matlab terbilang sederhana sehingga dapat dengan mudah digunakan. Pada bukunya yang berjudul Cepat Mahir Matlab,
Andry Pujiriyanto tahun 2004, mengungkapkan setidaknya ada 5 kegunaan Matlab secara umum yaitu untuk : a). Matematika dan komputasi; b). Pengembangan dan algoritma; c). Permodelan, simulasi dan pembuatan prototype; d). Analisa data, eksplorasi dan visualisasi; e). Pembuatan aplikasi 
termasuk pembuatan GUI (Graphical User Interface).

Pemanfaatan Matlab yang identik dengan matriks tentu erat kaitannya dengan bidang matematika dan komputasi. Berbagai permasalah matematika dapat dengan mudah dicari penyelesaiannya dengan Maltab, begitu pun dengan bidang komputasi. Matlab merupakan bahasa pemrograman level tinggi yang dikhususkan untuk kebutuhan komputasi teknis, visualisasi dan pemrograman seperti komputasi matematik, analisis data, pengembangan algoritma, simulasi dan pemodelan dan grafik-grafik perhitungan (Firmansyah, A. 2007). Masih dalam tulisan yang sama, ia mengungkapkan bahwa tugastugas matematika yang membutuhkan analisis ataupun perhitungan yang kompleks dan rumit dapat kita implementasikan dengan mudah dengan memanfaatkan fasilitas yang tedapat di Matlab. Pada bidang komputasi, Matlab dapat digunakan untuk akuisisi citra digital, termasuk juga dalam hal pengembangan dan algoritma. Permodelan, simulasi sampai pembuatan prototype juga berkaitan erat dengan komputasi. Demikian pula dengan kegunaan Matlab yang lain diatas, semua berkaitan dengan komputasi.

Penelitian dan pengembangan aplikasi dengan berbagai metode dalam pencitraan medis telah berkembang sangat luas (Setiawan, W. 2012). Berbagai aplikasi teknologi pencitraan medis banyak menggunakan Matlab sebagai sarana pengembangannya mulai dari deteksi, segmentasi, simulasi, bahkan sampai dalam pemrograman alat. $M A T L A B$ is often used by scientific researchers and biomedical engineers as it provides a high-level programming language that alleviates the users from lowlevel programming details such as memory management and pointer handling (Chu, V., \& Hamarneh, G, 2006). Lebih lanjut dalam artikelnya tersebut Chu, V \& Hamarneh mengungkapkan tugas periferal yang rumit, seperti pembuatan GUI, plot grafik, analisis statistik, dan akuisisi gambar 2D dapat dilakukan dengan pemanfaatan Matlab.

Salah satu penelitian yang pernah dilakukan yaitu "Aplikasi Alat Radiografi Digital dalam Pengembangan Layanan Foto Rontgen" oleh Susilo, dkk pada tahun 2012. Penelitian ini menghasilkan model prototype sistem pencitraan radiografi digital untuk pemeriksaan fraktur tulang dan software analisis pemeriksaan menggunakan Matlab. Hasil penelitian ini sekaligus juga mematahkan argumen bahwa radiografi digital identik dengan mahal, rumit dan membutuhkan sumber daya berkemampuan tinggi. Selain itu dengan software analisis berupa Matlab, hasil penelitian ini dapat dengan mudah diduplikasi oleh rumah sakit. Pada penelitian ini Matlab berfungsi sebagai software yang dapat mengubah data analisis kualitatif menjadi kuantitatif dengan mengubah tingkat keabuan citra hasil radiografi dalam bentuk angka 0 255 (dari gelap sampai terang) sesuai dengan tingkat keabuannya. Dengan demikian, pemanfaatan Matlab dalam aplikasi ini tentu akan mengurangi kesalahan analisis pemeriksa karena tingkat keabuan citra dapat dengan jelas digambarkan.

Terdapat 2 jenis teknologi pencitraan medis yaitu pencitraan medis analog dan digital. Pada pencitraan medis analog, digunakan film screen untuk menampilkan citra yang terbentuk dari radiografi. Sedangkan pada pencitraan digital, citra yang terbentuk disimpan dalam bentuk file digital sehingga teknologi ini dapat menghemat penggunaan film screen dan mempersingkat waktu proses pembacaan citra oleh tenaga medis. Karena file citra yang terbentuk dapat langsung diinterpretasikan. Teknologi pencitraan medis digital umumnya dianggap sebagai hal yang rumit, membutuhkan biaya yang 
mahal serta sumber daya manusia yang berkemampuan tinggi khususnya pada radiografi digital. Radiografi digital identik dengan teknologi Computed Radiograhy (CR) dimana citra radiografi yang terbentuk disimpan dalam bentuk file digital. Pada teknologi citra radiografi analog, citra yang terbentuk akan dicetak dalam bentuk film screen sedangkan pada teknologi CR citra yang terbentuk akan disimpan dalam bentuk file digital sebagai hasil dari akuisisi sinar - $\mathrm{x}$ yang melewati objek (Atina, 2017). Pemanfaatan Matlab telah mengalami perkembangan pesat khususnya dalam pengembangan sistem radiografi digital. Deteksi ketidaknormalan misalnya, citra yang terbentuk dari radiografi digital dapat tergambar dengan jelas baik dari pengembangan program segmentasi. Dewasa ini proses segmentasi citra medis dari hasil radiografi digital telah banyak dikembangkan. Sistem segmentasi ini didasarkan pada tingkat keabuan citra yang dijadikan sampel. Dalam bidang simulasi pun telah banyak dilakukan penelitian dengan menggunakan Matlab sebagai dasar pemrogramannya meski dengan metode yang berbeda-beda.

Beberapa hal yang perlu diperhatikan dalam pengolahan citra hasil radiorafi digital yaitu adalah proses prepengolahan,

Hal menarik lainnya yang perlu ditinjau dari aplikasi Matlab dalam teknologi pencitraan medis khususnya dalam pengolahan citra hasil radiografi digital yaitu aplikasi apa saja yang dapat dilakukan dengan memanfaatkan sofware Matlab. Aplikasi tersebut antara lain simulasi, segmentasi, deteksi dan pengembangan perangkat pencitraan medis.

\section{HASIL DAN PEMBAHASAN}

Berikut adalah beberapa hal yang perlu diperhatikan dalam pengolahan citra medis digital dengan aplikasi Matlab :

1. Pre-processing, pada proses ini citra hasil radiografi akan melewati tahap akuisisi, perataan histogram dan pengaturan size/ukuran citra. Semua proses ini diperlukan untuk mempermudah proses selanjutnya dan memperbaiki citra yang tidak memenuhi standar dalam hal pengaturan algoritma.

2. Proses pengolahan citra, proses ini baru dapat dilakukan jika citra hasil radiografi telah melalui tahap preprocessing. Proses pengolahan citra membutuhkan waktu yang bervariasi namun hal ini bergantung pada kualitas citra seperti ukuran citra; algoritma yang disusun; hardware yang digunakan; keahlian tenaga medis/operator.

3. Analisis data dan simpulan, proses analisis data yang dimaksud adalah interpretasi dari hasil pengolahan citra. Pada Matlab, algoritma ini juga dapat disusun. Namun interpretasi data ini juga dapat dilakukan secara manual oleh tenaga medis/operator, terlebih lagi jika program yang disusun untuk tujuan simulasi atau pengembangan awal program.

Beberapa aplikasi yang telah dilakukan pada teknologi pencitraan medis dengan menggunakan Matlab :

1. Segmentasi

Proses segmentasi dilakukan umumnya dengan tujuan akhir untuk mendeteksi adanya kelainan pada organ tertentu. Prinsip dasar proses segmentasi adalah membagi/mengelompokkan bagianbagian citra kedalam kelompok yang didasarkan pada kedekatan kesamaan bagian-bagian tersebut menjadi beberapa cluster. Kriteria kedekatan ini disesuaikan dengan algoritma yang disusun pada 
Matlab. Meski menggunakan software yang sama, namun teknik yang digunakan dapat bervariasi. Teknik segmentasi yang tersedia pada Matlab diantaranya k-Means Clustering, Fuzzy C-Mean, Active Contour, algoritma deteksi tepi, metode Otsu Thresholding. Objek segmentasi pun dapat berbagai jenis organ, dengan demikian algoritma yang disusun dapat disesuaikan dengan teknik dan organ yang menjadi objek.

Pada 2014, Fakhrurrozi Basyid dan Kusworo Adi melakukan segmentasi citra medis untuk pengenalan objek kanker menggunakan metode active contour. Segmentasi yang dilakukan menggunakan algoritma yang disusun menggunakan Matlab 2008a. Segmentasi ini dilakukan untuk membedakan sel-sel kanker dengan sel-sel sehat. Hasil penelitian ini menunjukkan bahwa segmentasi dengan metode active contour dapat melakukan segmentasi dengan objek multi region, objek yang saling berdekatan namun sensitif terhadap citra berderau (Fakhurrozi Basyid, Kusworo Adi, 2014).

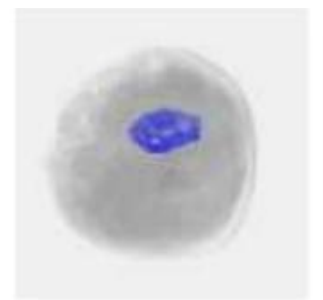

(b)

(a)

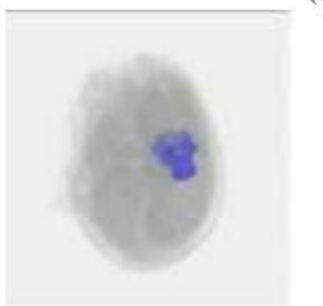

(c)

Gambar 1. Citra hasil contour 3D (a) posisi axial PTV; (b) posisi saggital PTV; (c) posisi coronal PTV (Sumber : Fakhurrozi Basyid, Kusworo Adi, 2014)

2. Simulasi

Pemanfaatan Matlab dengan tujuan simulasi umumnya untuk proses pembelajaran atau uji coba pengembangan program. Sama halnya dengan proses segmentasi, proses simulasi pun dapat dikembangkan sesuai dengan kebutuhan. Samuel Gideon pada tahun 2015 menuliskan algoritma Matlab yang digunakan untuk membuat citra daerah pelvis dalam artikelnya yang berjudul Pembelajaran Simulasi Pencitraan CT dengan Menggunakan Prinsip Rekonstruksi Citra dalam Software Matlab. Berikut adalah citra hasil penelitian yang dilakukannya : 

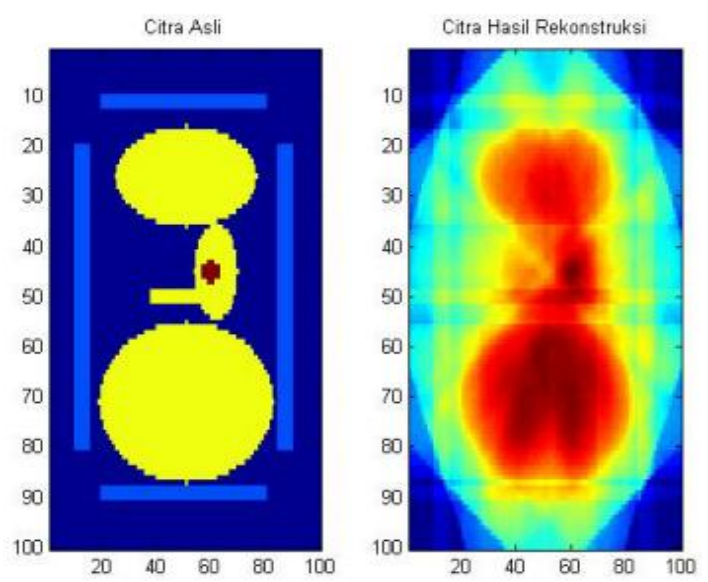

Gambar 2. Citra asli dan hasil rekonstruksi biasa (Sumber : Samuel Gideon, 2015).

Gambarr 2. menunjukkan citra asli dan citra hasil rekkonstruksi biasa (tanpa filter). Pada penelitiannya ini Samuel
Gideon juga melakukan rekonstruksi dengan filter. Hasil rekonstruksi dengan filter ditunjukkan pada gambar 3.

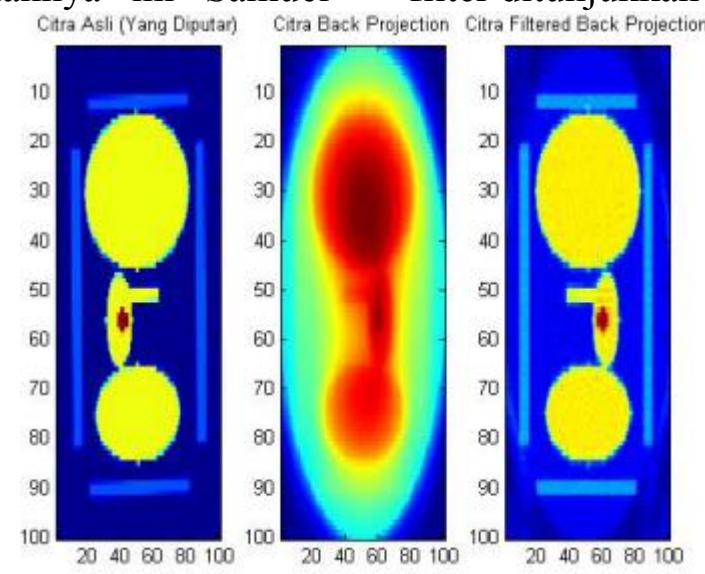

Gambar 3. Perbandingan hasil rekonstruksi (Sumber : Samuel Gideon, 2015).

Hasil penelitian ini menunjukkan bahwa citra hasil rekonstruksi dengan filter dapat memvisualisasikan citra yang menyerupai aslinya.

\section{Pengembangan Program}

Matlab dioperasikan pada perangkat keras seperti mikrokontroler. Jean Rossario Raj dengan 2 orang rekannya pada tahun 2016 menciptakan prototype mikrokontroler untuk scanner ultrasound.

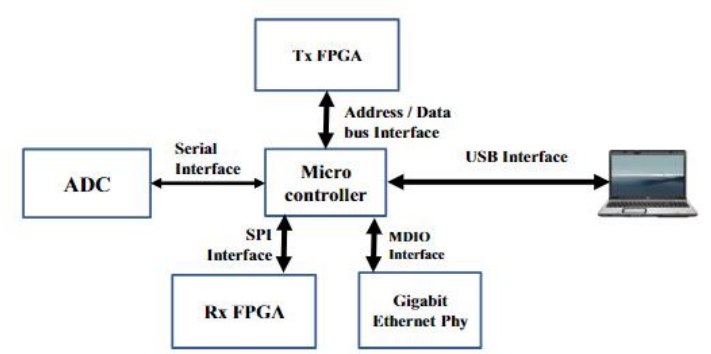

Gambar 4. Skema penelitian yang dilakukan Jean Rossario Raj dkk (Sumber : Raj, J. R., Rahman, S. M. K., \& Anand, S. 2016) 


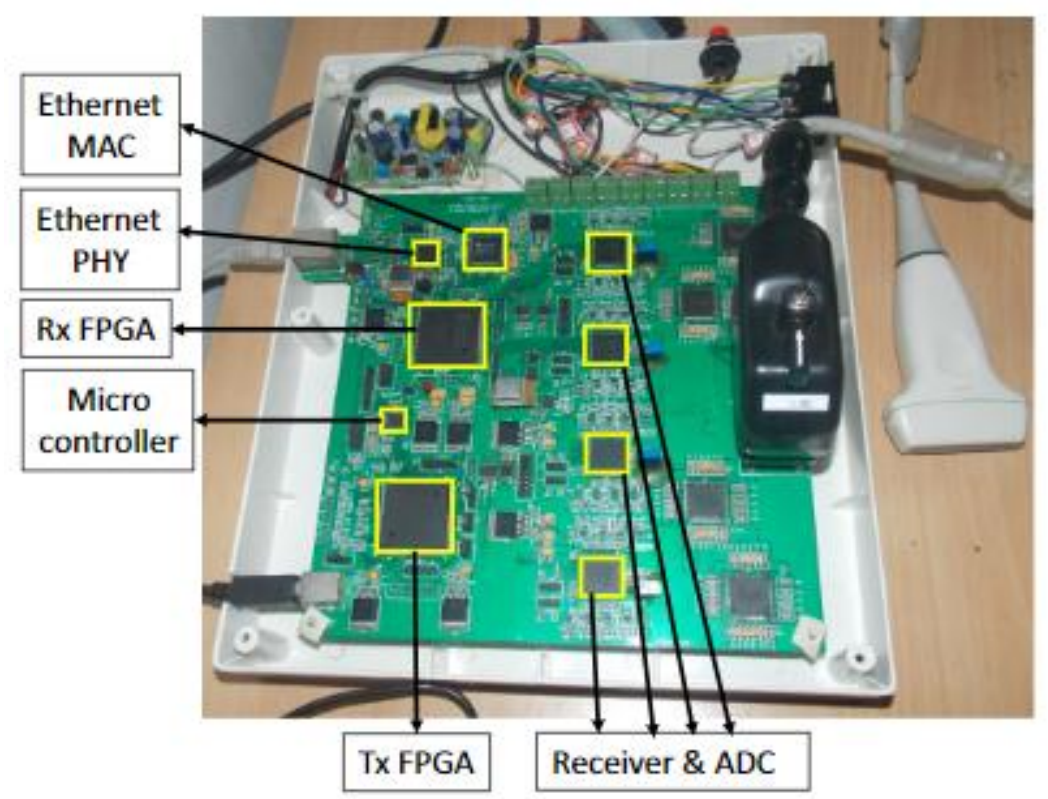

Gambar 5.

Perangkat keras Prototype scanner ultrasound yang dihasilkan oleh Jean Rossario Raj dkk (Sumber : Raj, J. R., Rahman, S. M. K., \& Anand, S. 2016).

\section{KESIMPULAN}

Proses pengembangan aplikasi Matlab dalam teknologi pencitraaan medis khususnya radiografi digital terus berkembang dengan berbagai tujuan diantara untuk deteksi kelainan organ, segmentasi, simulasi bahkan pengembangan pemrograman peralatan medis.

\section{Ucapan Terima Kasih (jika diperlukan)}

Terima kasih yang tak terhingga kepada semua pihak yang terlibat dalam penulisan artikel ini, khususnya para penulis yang tulisannya disitasi pada artikel ini. Kepada rekan-rekan sejawat di lingkungan program studi fisika yang telah mensupport dalam penyelesaian tulisan ini, semoga karya kedepan semakin baik.

\section{DAFTAR PUSTAKA}

Atina, A. (2017). Segmentasi Citra Paru Menggunakan Metode k-Means Clustering. Jurnal Pendidikan
Fisika dan Keilmuan
(JPFK), 3(2), 57-65.

Basyid, F., \& Adi, K. (2014). Segmentasi

Citra Medis untuk Pengenalan

Objek Kanker menggunakan

Metode Active

Contour. Youngster Physics

Journal, 3(3), 209-216.

Chu, V., \& Hamarneh, G. (2006, March). MATLAB-ITK interface for medical image filtering, segmentation, and registration. In Medical Imaging 2006: Image Processing (Vol. 6144, p. 61443T). International Society for Optics and Photonics.

Firmansyah, A. (2007). Dasar-dasar Pemrograman Matlab. IlmuKomputer. com.

Gideon, S. (2015). Pembelajaran Simulasi Pencitraan Ct Dengan Menggunakan Prinsip Rekonstruksi Citra Dalam Software Matlab. Jurnal Dinamika Pendidikan, 8(3), 161170.

Prasetyo, E. (2011). Pengolahan Citra Digital dan Aplikasinya 


\section{Aplikasi Matlab pada...Jupiter... Vol 1 No 1...Juli 2019...28-34}

Atina Atina

Menggunakan

Matlab. Yogyakarta: Andi.

Raj, J. R., Rahman, S. M. K., \& Anand, S. (2016). Microcontroller USB interfacing with MATLAB GUI for low cost medical ultrasound scanners. Engineering Science and Technology, an International Journal, 19(2), 964-969.

Sasono, M. (2006, November). Simulasi MATLAB Rekonstruksi Citra
Tomografi dengan Metode

Proyeksi Balik Terfilter.

In Prosiding Seminar Nasional Surabaya (Vol. 1, No. 1, Pp. 181187). FMIPA ITS Surabaya.

Setiawan, W. (2012). Sistem Deteksi Retinopati Diabetik Menggunakan Support Vector Machine. 